\title{
Effect of irrigation water salinity and cutting age on the components of biomass of Echinochloa pyramidalis
}

\author{
Luiz Barreto de Morais Neto ${ }^{1}$, Maria Socorro de Souza Carneiro ${ }^{2}$, Claudivan Feitosa de \\ Lacerda $^{3}$, Marcus Roberto Góes Ferreira Costa ${ }^{1}$, Rildson Melo Fontenele ${ }^{1}$, José Valmir Feitosa ${ }^{4}$ \\ 1 Programa de Doutorado em Zootecnia - PDIZ (UFC/UFPB/UFRPE). \\ 2 Departamento de Zootecnia - UFC. \\ ${ }^{3}$ Departamento de Engenharia Agrícola - UFC. \\ ${ }^{4}$ Departamento de Agronomia - UFC.
}

\begin{abstract}
The objective was to evaluate the effect of salinity of irrigation water and different cutting ages on the biomass components of Echinochloa pyramidalis. Seedlings were planted in plastic pots (volume of $8 \mathrm{~L}$ ) with sandy-textured Quartzarenic Neosol, under greenhouse conditions. The design was completely randomized in split plots with salinity levels $\left(0.75,2.0,4.0,6.0\right.$ and $\left.8.0 \mathrm{dS} \mathrm{m}^{-1}\right)$ in the main plot, and cutting ages $(21,28,35,42$ and 49 days) in the subplots, with five replicates. After the standardization cut, the dry masses of total forage, dead forage, live forage, green leaf blade, green stem and ratios of live material/dead material and leaf/stem were determined. There was no interaction between the factors studied. Salinity decreased the dry masses of total forage, green leaf blade and green stem. Salinity had no effect on the dry masses of dead forage or ratios of live material/dead material and leaf/stem. Salinity changed the partitioning of dry matter, reducing the percentage of stems, and increasing the percentage of leaves in the dry mass of total forage. The advance in the cutting age caused increases in the dry masses of total forage, dead forage, live forage, green stem and green leaf blade. From the cutting age of 28 days, dead forage dry mass had a very sharp increase. The increase in stem dry mass rose from the $35^{\text {th }}$ day. The extension of the cutting age promoted a decline in the live material/dead material and leaf/stem ratios. The cut of Echinochloa pyramidalis at 21 days, when it presents the best leaf/stem ratio is recommended.
\end{abstract}

Key Words: dry matter partitioning, Echinochloa pyramidalis, forage dry mass

\section{Introduction}

In an attempt to raise the forage production during the dry season and to mitigate the effects of short summers, the irrigation of pastures has been used in several properties (Souza et al., 2005). Especially in regions where winter temperatures are not limiting to plant growth, as the semiarid Northeast, this technique represents a viable alternative by presenting satisfactory results in terms of food shortage in the dry period (Lopes et al., 2005). This involves, among other things, the use of saline water sources, common in semi-arid regions (Ayres \& Westcot, 1999), as well as the reuse of drainage water with high levels of salt and employment of species able to present high profitability when irrigated with these types of water (Rhoades et al., 1992; Seckler et al., 1998).

The use of these water sources in irrigated agriculture should be preceded by studies that show its impact on the quantity and quality of agricultural products and also on the soil properties (Sharma \& Rao, 1998; Annandale et al., 1999), aiming to find more adapted genotypes and the most appropriate techniques to reduce its effects on the environment.

Echinochloa pyramidalis is a widely used forage grass, especially in areas with weir dams, ponds, river banks and lowlands. In Ceará State, many lowland areas have been degraded by the excessive accumulation of salts, mainly due to the misuse of irrigation for successive years of rice cultivation. Besides that, many of these lands are subjected to flooding for much of the year.

In this way, it was verified that the Echinochloa pyramidalis, besides surviving under these conditions, provides forage with quality and in quantity fairly attractive for raising ruminants. Even with quite interesting potential, scientific studies on this species are almost inexistent.

This study aimed at evaluating the effect of water salinity and different cutting ages on the biomass components of Echinochloa pyramidalis.

\section{Material and Methods}

The experiment was conducted under greenhouse conditions of the Department of Soil Sciences of the 
Universidade Federal do Ceará, in Fortaleza municipality, located at coordinates $3^{\circ} 44^{\prime} \mathrm{S}$ latitude and $38^{\circ} 44^{\prime} \mathrm{W}$ longitude. The region climate is classified, according to Köppen, as of the type Aw', with rainy tropical climate.

In the preparation of the seedlings, the stems were cut, each one forming piles with three gems. Then, they were planted in pots with volume of eight liters, containing airdried soil, and buried up to the second gem. The soil was obtained from Guarany farm, in Pacajus municipality, Ceará State, located at coordinates $4^{\circ} 10^{\prime}$ S latitude and $38^{\circ} 28^{\prime} \mathrm{W}$ longitude, with rainy tropical climate. The soil was collected from the surface layer $(0-30 \mathrm{~cm})$ and classified as Quartzarenic Neosol, sandy texture, and sieved using a 4-mm mesh sieve. After collection, the soil was taken to the Laboratory of the Department of Soil Sciences of the Universidade Federal do Ceará and subjected to physical and chemical analyses, according to methodology described in the handbook of methods and analysis of soils (Embrapa, 1997) (Table 1).

Seedlings were irrigated with tap water with electrical conductivity (ECa) of $0.75 \mathrm{dS} \mathrm{m}^{-1}$ (control) until 56 days after planting, when the standardization cut was done. Then the treatments began to be applied.

The experiment consisted of five salinity levels $(0.75$; 2.0; 4.0; 6.0 and $8.0 \mathrm{dS} \mathrm{m}^{-1}$ ) and five cutting ages (21; 28; 35; 42 and 49 days), with five replicates, distributed in a split plot design, with the salinity levels in the main plot and the cutting ages in the subplots, totalizing 125 experimental units, in which the experimental unit was represented by each pot containing three plants. The standardization cut was made on April $16^{\text {th }}, 2008$, at $20 \mathrm{~cm}$ from the ground level, and the cuts for data collection were performed on the schedule according to the treatments.

For the preparation of the salt solutions, $\mathrm{NaCl}$, $\mathrm{CaCl}_{2} \cdot 2 \mathrm{H}_{2} \mathrm{O}$ and $\mathrm{MgCl}_{2} \cdot 6 \mathrm{H}_{2} \mathrm{O}$ were applied at a ratio 7:2:1, obeying the relationship between ECa and concentration (mmol $\left.\mathrm{L}^{-1}=\mathrm{EC} \times 10\right)$, according to Rhoades et al. (1992). The amount of water applied was calculated to meet the crop

Table 1 - Physical and chemical characteristics of the soil used in the experiment with Echinochloa pyramidalis Characteristic

\begin{tabular}{lc} 
Textural classification & Areia franca \\
\hline Global density $\left(\mathrm{g} \mathrm{cm}^{-3}\right)$ & 1.24 \\
pH in water & 5.6 \\
$\left.\mathrm{EC}(\mathrm{dS} \mathrm{m})^{-1}\right)$ & 0.12 \\
$\mathrm{Ca}^{2+}\left(\mathrm{cmol}_{\mathrm{c}} \mathrm{g}^{-1}\right)$ & 1.7 \\
$\mathrm{Mg}^{2+}\left(\mathrm{cmol}_{\mathrm{c}} \mathrm{kg}^{-1}\right)$ & 1.7 \\
$\mathrm{Na}^{+}\left(\mathrm{mg} \mathrm{kg}^{-1}\right)$ & 11 \\
$\mathrm{~K}^{+}\left(\mathrm{mg} \mathrm{kg}^{-1}\right)$ & 70 \\
$\mathrm{Al}^{3+}\left(\mathrm{cmol}_{\mathrm{c}} \mathrm{kg}^{-1}\right)$ & 0.05 \\
ESP $(\%)$ & 1.08 \\
\hline
\end{tabular}

EC = electrical condutivity; ESP = exchangeable sodium percentage. requirements and add a leaching fraction of $15 \%$ to prevent excessive accumulation of salts (Ayres \& Westcot, 1999). The fertilization of the plants was made through weekly applications of $200 \mathrm{~mL}$ of the Hoagland nutrient solution (Epstein, 1975), using a graduated flask.

After each cut, the material was fractionated into leaf, stem and sheath and dead material, taken to the laboratory to be weighed, dried in forced ventilation oven at $55^{\circ} \mathrm{C}$ until constant weight. With these data, the following components of forage biomass were calculated: dry mass of total forage (mass of leaves + stems and sheath + mass of dead material); dry mass of green forage (mass of leaves + mass of stems and sheath); dry mass of dead forage; dry mass of green leaf blade; dry mass of green stem; live material/dead material ratio (mass of green forage/mass of dead forage) and leaf/ stem ratio.

Data were subjected to analysis of variance (ANOVA) and $\mathrm{F}$ test. The mean values were compared by the Tukey test at 5\% probability, and for the estimates of cutting age and salinity levels, a regression analysis was performed, using the software SISVAR (Sistema de Análise de Variância, version 4.0, 1999).

\section{Results and Discussion}

There was significant effect of the salinity levels $(\mathrm{P} \leq 0.05)$ on the dry mass of total forage, dry mass of green forage, dry mass of green leaf blade and dry mass of green stem (Table 2). The values of masses of total forage and green forage were similar in the salinity levels: 0.75 and $2.0 \mathrm{dS} \mathrm{m}^{-1}$. However, the values at $0.75 \mathrm{dS} \mathrm{m}^{-1}$ were higher than the other treatments. No difference was detected in the values of dry masses of green leaf blade and green stem between the treatments $0.75 ; 2.0$ and $4.0 \mathrm{dS} \mathrm{m}^{-1}$. Also no difference was verified between the treatments for dry mass of dead forage, live material/dead material and leaf/stem ratios.

The dry mass of total forage was influenced by the salinity, presenting an inverse linear relationship (Figure 1). This can be explained by several factors, such as: osmotic effect, once a high concentration of salt decreases the soil osmotic potential, causing a greater retention of water, making it available at lower quantity to the plant (Gheyi, 2000); and toxic effect, characterized by the accumulation of specific ions in the plant. For instance, an excess of $\mathrm{Na}^{+}$and $\mathrm{Cl}^{-}$in the protoplasm affects the photophosphorylation, the respiratory chain, the nitrogen assimilation and the protein metabolism. These ions begin to inhibit most enzymes involved in this processes at a concentration above $100 \mathrm{mM}$ (Larcher, 2000; Munns, 2002), nutritional effect in which the excess of an ion in the soil inhibits the absorption of other 
Table 2 - Effect of the treatments on the dry mass of total forage (DMTF), dry mass of green forage (DMGF), dry mass of dead forage (DMDF), dry mass of green leaf blade (DMGL), dry mass of green stem (DMGS), live material/dead material ratio (LM/DM) and leaf/stem ratio (L/S) of Echinochloa pyramidalis under five salinity levels (ECa) in the irrigation water

\begin{tabular}{|c|c|c|c|c|c|c|c|}
\hline \multirow[t]{2}{*}{ Variable } & \multicolumn{5}{|c|}{ Salinity levels (ECa) } & \multirow[t]{2}{*}{$\mathrm{R}^{2}$} & \multirow[t]{2}{*}{$\mathrm{P}$} \\
\hline & 0.75 & 2.0 & $\begin{array}{c}4.0 \\
\mathrm{dS} / \mathrm{m}\end{array}$ & 6.0 & 8.0 & & \\
\hline $\mathrm{DMTF}^{1}$ & 8.80 & 8.48 & 7.54 & 7.12 & 6.58 & 0.9790 & 0.00001 \\
\hline $\mathrm{DMDF}^{2}$ & 1.89 & 1.86 & 1.78 & 1.69 & 1.68 & - & - \\
\hline $\mathrm{DMGF}^{3}$ & 6.94 & 6.81 & 5.76 & 5.23 & 4.90 & 0.9501 & 0.00001 \\
\hline $\mathrm{DMGL}^{4}$ & 2.64 & 2.62 & 2.22 & 2.08 & 2.05 & 0.8594 & 0.0002 \\
\hline $\mathrm{DMGS}^{5}$ & 4.30 & 4.19 & 3.54 & 3.17 & 2.81 & 0.9689 & 0.00001 \\
\hline $\mathrm{LM} / \mathrm{DM}^{6}$ & 6.97 & 6.72 & 7.26 & 4.99 & 5.13 & - & - \\
\hline $\mathrm{L} / \mathrm{S}^{7}$ & 0.66 & 0.68 & 0.68 & 0.69 & 0.77 & 0.7023 & 0.0362 \\
\hline
\end{tabular}

$1 \underset{\sim}{Y}=8.864-0.289 \mathrm{SL}^{*}$

$2 \tilde{Y}=6.21 \mathrm{ND}$.

$3 \hat{Y}=7.057-0.282 \mathrm{SL}^{*}$.

$4 \hat{Y}=2.657-0.083 L^{*}$.

$5 \hat{Y}=4.400-0.199 S^{*}$.

$6 \tilde{\mathrm{Y}}=6.21 \mathrm{ND}$

$7 \hat{Y}=0.654+0.010$ SL $^{*}$.

$*=\mathrm{P} \leq 0.05 ; \mathrm{ND}=$ not different; SL = salinity levels.

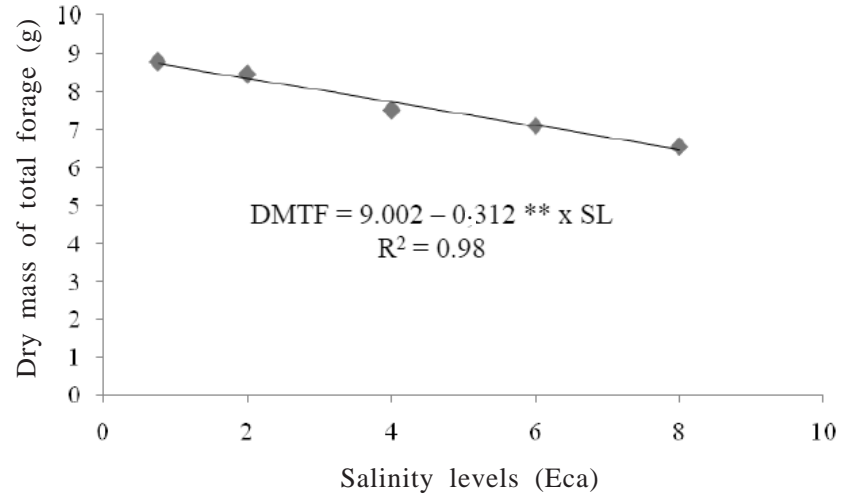

Figure 1 - Variation in the dry mass of total forage (DMTF) as a function of the salinity levels of the irrigation water in Echinochloa pyramidalis.

ions, e.g., when the concentration of $\mathrm{Na}^{+}$and $\mathrm{Cl}^{-}$in the soil is high, the absorption of mineral nutrients, especially $\mathrm{NO}_{3}{ }^{-}$, $\mathrm{K}^{+}$and $\mathrm{Ca}_{2}{ }^{+}$is almost always reduced.

The decrease in the dry mass of total forage with increasing salinity in the irrigation water was influenced by the decline in the dry mass of green forage (Figure 2); the same was not observed for the dry mass of dead forage. These results diverge from what was reported by Prisco \& O’Leary (1972) and Lutts et al., (1996), who have suggested that the salt stress speeds up the leaf senescence, due to the lower biosynthesis of cytokinins in the roots, as well as the reduction in their transportation to the aerial part, which is a consequence of changes in metabolism of the root cells.

The reduction in the dry mass of green forage was more intensely affected by the decline in dry mass of green stem

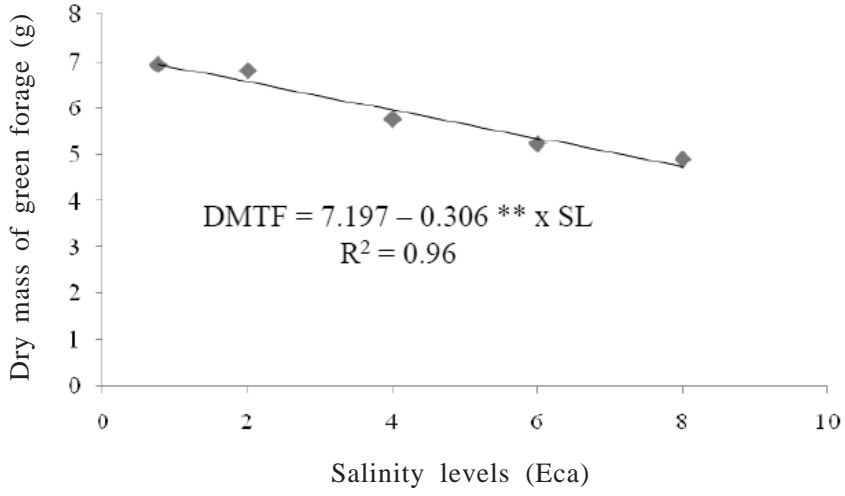

Figure 2 - Variation in the dry mass of green forage (DMGF) as a function of the salinity levels of the irrigation water in Echinochloa pyramidalis.

(Figure 3) than of the dry mass of green leaf blade (Figure 4), since there was a decrease of $52.79 \%$ in the dry mass of green stem, while in the dry mass of green leaf blade, only a reduction of $28.48 \%$ was verified between the treatments of 0.75 and $8.0 \mathrm{dS} \mathrm{m}^{-1}$. Still, in terms of partitioning of total dry matter, the dry mass of green leaf blade represented $29.91 \%$ and $31.21 \%$, while the dry mass of green stem was equal to $48.84 \%$ and $42.74 \%$ in the treatments 0.75 and $8.0 \mathrm{dS} \mathrm{m}^{-1}$, respectively.

The dry mass of green leaf increased its percentage in the dry mass of total forage, while the dry mass of green stem had a decline with increasing salinity. The percentage increase of the dry mass of green leaf blade in relation to dry mass of total forage, in response to the increased water salinity, can reflect the different sensitivities of the vegetative organs to salt 


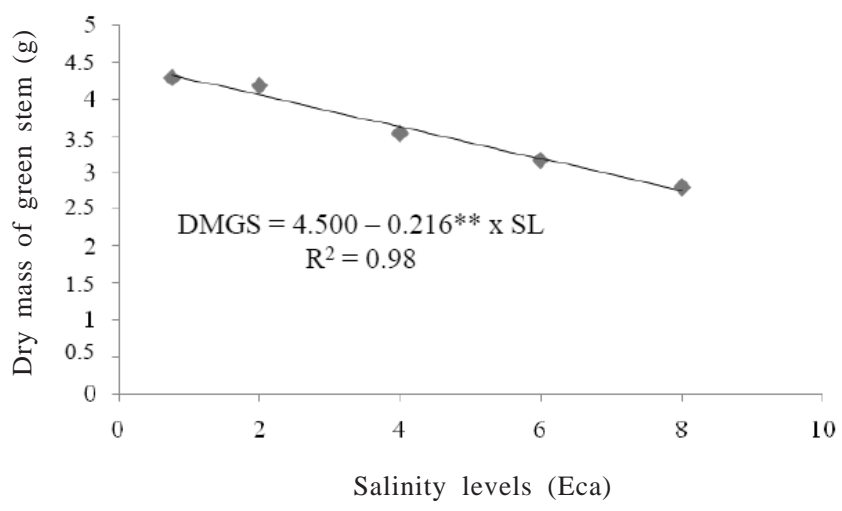

Figure 3 - Variation in the dry mass of green stem (DMGS) as a function of the salinity levels of the irrigation water in Echinochloa pyramidalis.

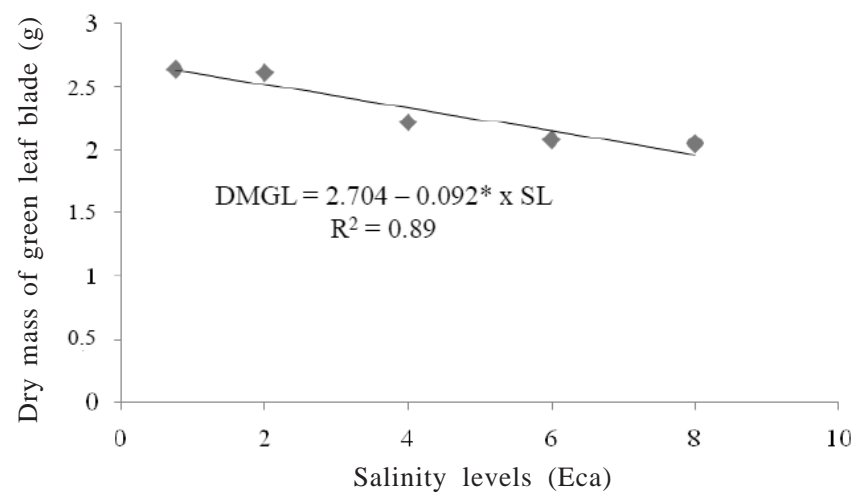

Figure 4 - Variation in the dry mass of green leaf blade (DMGL) as a function of the salinity levels of the irrigation water in Echinochloa pyramidalis. stress or different protection mechanisms that the plants use for their various parts (Aquino et al., 2007). These variations in the percentages of the dry mass of total forage caused by increasing salinity are consistent with the fact that the salinity, besides reducing biomass production, can also change the partitioning of photoassimilates among plant parts (Greenway \& Munns, 1980; Silva et al., 2003).

These differences in the partitioning of the dry mass of total forage can contribute to the acclimation of plants to salt stress, offsetting the reduction in leaf area destined to carbon assimilation. These changes in the source/sink ratio offset the increase in metabolic expenditure required for the adjustment of the plant to the stress imposed (Munns, 2002; Aquino et al, 2007).

Salinity had no influence on the live material/dead material or leaf/stem ratios. Despite this, a slight increase was observed in leaf/stem, improving the source/sink ratio.

A significant difference was registered $(\mathrm{P} \leq 0.05)$ between the cutting ages considering the examined variables (Table 3 ). At cutting ages 21 and 28 days, the lowest values of dry masses of total forage and green forage were verified, increasing with advancing plant age were verified. An increasing linear trend was verified in the dry mass of dead forage, which was significant between all analyzed ages. The lowest value of dry mass of green leaf was observed at cutting age of 28, and the dry mass of green stem was similar between the cutting age of 21 and 28 days, tending to rise, with the highest production at cutting age of 49 days. The cutting age of 21 days achieved a value of the live material/ dead material ratio higher than observed in the other ages. The highest leaf/stem ratio was observed at age of 21 days.

The dry mass of total forage was influenced by the cutting age (Figure 5) from 28 days. This is a consequence

Table 3 - Effect of the cutting ages on the dry mass of total forage (DMTF), dry mass of green forage (DMGF), dry mass of dead forage (DMDF), dry mass of green leaf blade (DMGL), dry mass of green stem (DMGS), live material/dead material ratio (LM/DM) and leaf/stem ratio (L/S) of Echinochloa pyramidalis under five cutting ages

\begin{tabular}{|c|c|c|c|c|c|c|c|}
\hline \multirow[t]{2}{*}{ Variable } & \multicolumn{5}{|c|}{ Cutting age } & \multirow[t]{2}{*}{$\mathrm{R}^{2}$} & \multirow[t]{2}{*}{$\mathrm{P}$} \\
\hline & 21 & 28 & 35 & 42 & 49 & & \\
\hline $\mathrm{DMTF}^{1}$ & 5.31 & 5.84 & 7.85 & 9.05 & 10.50 & 0.9795 & 0.00001 \\
\hline $\mathrm{DMDF}^{2}$ & 0.38 & 1.01 & 1.93 & 2.56 & 3.01 & 0.9868 & 0.00001 \\
\hline $\mathrm{DMGF}^{3}$ & 4.92 & 4.83 & 5.91 & 6.48 & 7.50 & 0.9270 & 0.00001 \\
\hline $\mathrm{DMGL}^{4}$ & 2.29 & 2.06 & 2.35 & 2.37 & 2.55 & 0.5553 & 0.0065 \\
\hline $\mathrm{DMGS}^{5}$ & 2.64 & 2.77 & 3.56 & 4.12 & 4.94 & 0.9625 & 0.00001 \\
\hline $\mathrm{LM} / \mathrm{DM}^{6}$ & 16.40 & 6.07 & 3.38 & 2.71 & 2.61 & 0.6984 & 0.00001 \\
\hline $\mathrm{L} / \mathrm{S}^{7}$ & 0.90 & 0.77 & 0.68 & 0.60 & 0.54 & 0.9801 & 0.00001 \\
\hline
\end{tabular}

$*=\mathrm{P} \leq 0.05 ; \mathrm{CA}=$ cutting age.

$1 \hat{Y}=0.905+0.194 C^{*}$.

$2 \hat{Y}=-1.623+0.097 \mathrm{CA} *$.

${ }^{3} \hat{Y}=2.528+0.097 C^{*}$.

$4 \hat{Y}=1.902+0.012 \mathrm{CA} *$.

$5 \hat{Y}=0.626+0.085 \mathrm{CA} *$.

$6 \hat{Y}=21.710-0.442 \mathrm{CA} *$

$7 \hat{Y}=1.138-0.012 \mathrm{CA}^{*}$ 
of the increase in dry mass of dead forage (Figure 6) and dry mass of green forage; it can also be said that the dry mass of dead forage contributes more intensely than the dry mass of green forage for this fact, since the dry mass of dead forage had an increase of $688.71 \%$ between the cutting ages of 21 and 49 days, while the dry mass of green forage increased only $52.24 \%$ between the same cutting ages.

Several studies have evaluated forage at different ages, and many obtained a trend in the dry mass of total forage similar to that found in the present study, since they also observed an increase in the dry mass of total forage with advancing age, which was fairly influenced by the dry mass of dead forage, due to the beginning of the senescence process with advancing age (Cândido, 2003; Bueno, 2003; Barbosa, 2004; Silva, 2004; Cutrim Junior, 2006).

With advancing age, the leaf area increased and shadowed the lower canopy layers, achieving a critical leaf area index. According to Brougham (1958), this critical leaf area index is that in which the canopy intercepts $95 \%$ of the

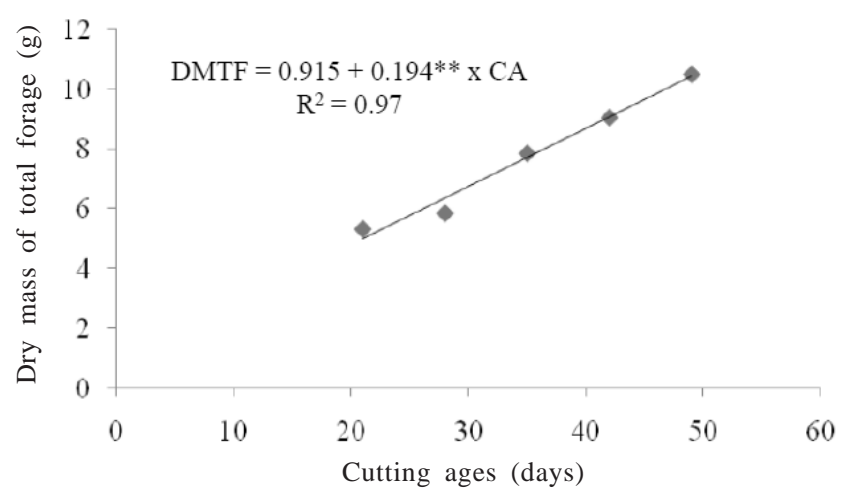

Figure 5 - Dry mass of total forage (DMTF) of Echinochloa pyramidalis at different cutting ages under the effect of the salinity levels of the irrigation water.

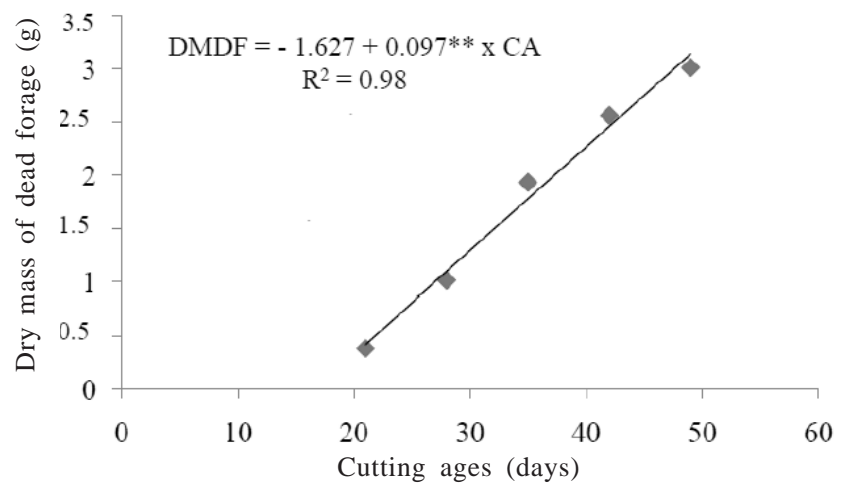

Figure 6 - Dry mass of dead forage (DMDF) of Echinochloa pyramidalis at different cutting ages under the effect of the salinity levels of the irrigation water. photosynthetically active radiation. From this point, due to the mutual shading, the senescence process starts (Hunt, 1965; Korte et al., 1982). Given this, it is estimated that the critical leaf area index had been achieved at cutting age of 28 days, which could explain the sharp increase in the dry mass of dead forage soon after this age (165.09\% between the cutting age of 21 and 28 days) (Figure 9).

The increase in the dry mass of green forage was due to the increases of both dry mass of green leaf blade (Figure 7) and dry mass of green stem (Figure 8). The latter contributed more strongly to dry mass of green forage, since it had an increase of $87.41 \%$, while the accumulation of dry mass of green leaf blade was only $11.67 \%$ at the last cutting in relation to the first.

As the forage mass increases, the shading of the lower canopy layers also increases, with changes in the quantity and quality of light that reaches the base of the plant. With regard to quality, the most significant change was relative to the wavelengths red/extreme red. Considering that red is

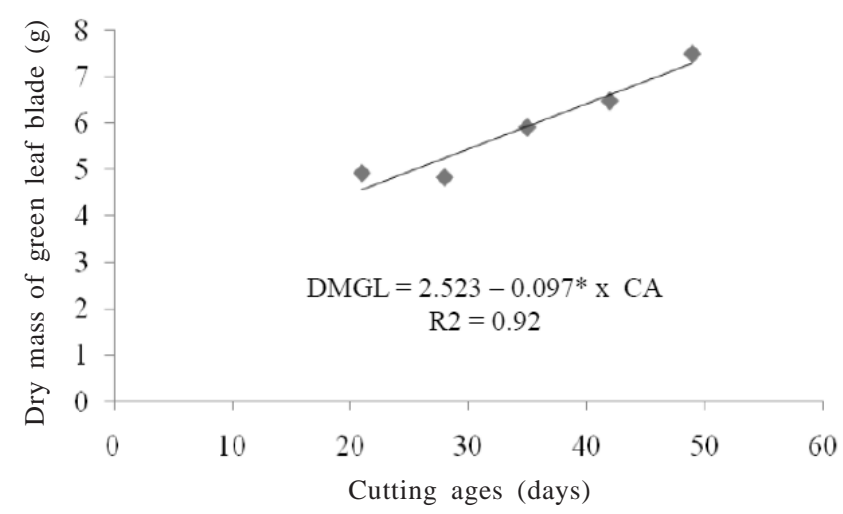

Figure 7 - Dry mass of green leaf blade(DMGLB) of Echinochloa pyramidalis at different cutting ages under the effect of the salinity levels of the irrigation water.

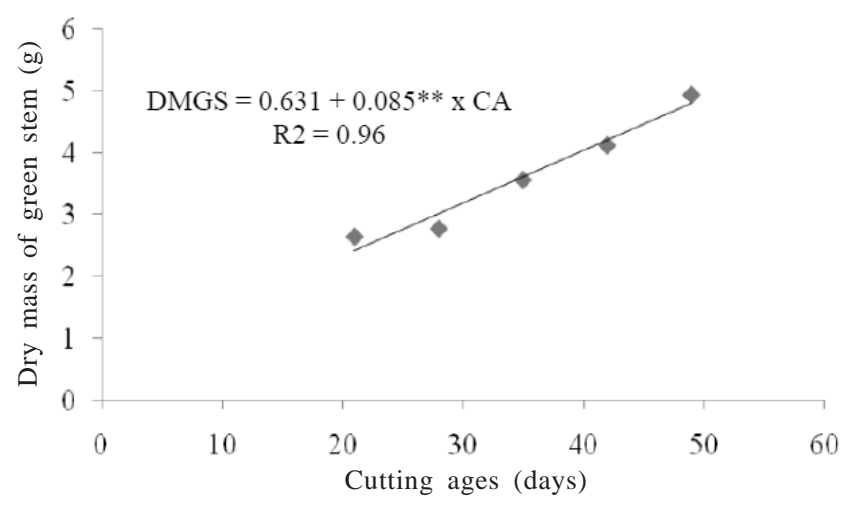

Figure 8 - Dry mass of green stem (DMGS) of Echinochloa pyramidalis at different cutting ages under the effect of the salinity levels of the irrigation water. 
more effective in photosynthesis, the red/extreme red ratio tends to decrease as the light penetrates in the canopy. These changes in the amount and quality of light along the canopy profile not only affect the photosynthetic capacity of leaves, but can also trigger morphophysiological processes of plant adjustment to the new light environment (Cândido, 2003). According to Taiz \& Zeiger (2004) after the change in light quality is detected by the phyllocron, there is the start of the stem elongation in an attempt to temporarily minimize the shading of the lower layers. In general, this process begins after reaching the critical leaf area index.

The greater accumulation of dry mass of green stem, in comparison with dry mass of green leaf and its higher contribution to dry mass of green forage, once the critical leaf area index of Echinochloa pyramidalis in this study should have reached around 28 days, triggers the process of stem elongation, causing a significant increase in the dry mass of green stem.

At 21 days, the live material/dead material ratio (Figure 9) was higher than in the other ages, and this can be explained by the acceleration of the senescence process after this

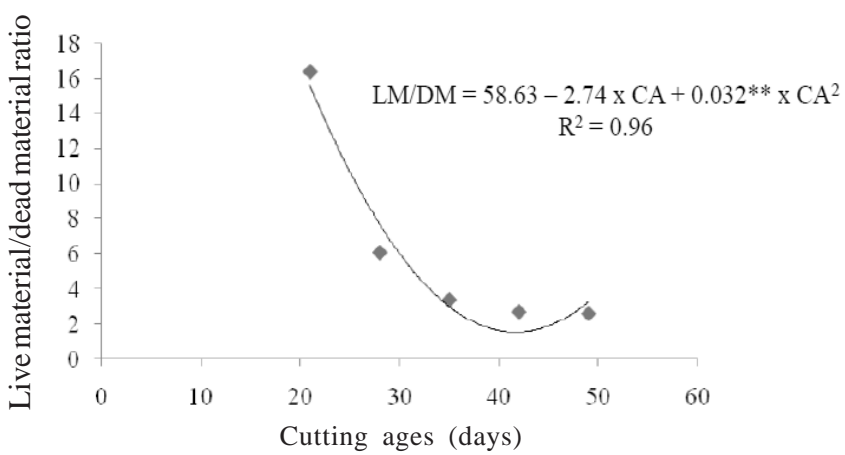

Figure 9 - Live material/dead material ratio of Echinochloa pyramidalis at different cutting ages under the effect of salinity levels in the irrigation water.

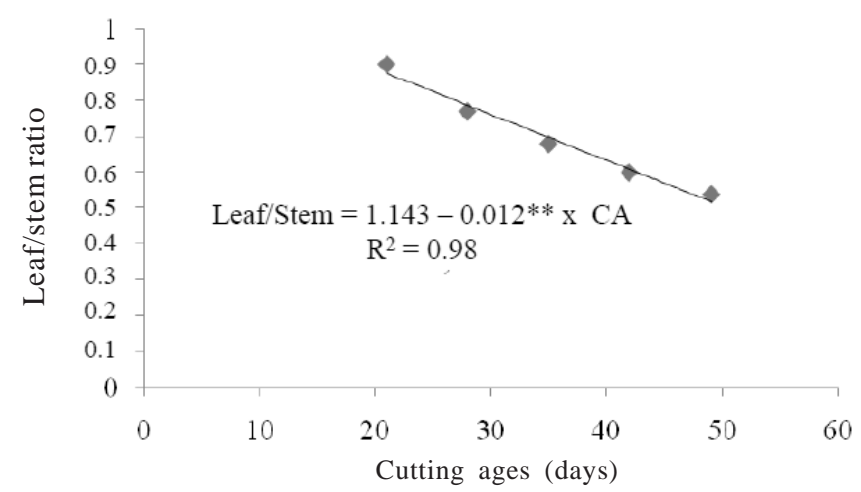

Figure 10 - Leaf/stem ratio of Echinochloa pyramidalis in different cutting ages under the effect of increasing levels in irrigation water. age. From the moment when the senescence process was accelerated, accumulation of stems also occurred, increasing the amount of green material and causing a balance of this relationship, presenting a quadratic behavior.

The leaf/stem ratio varied inversely to cutting age (Figure 10). This was due to the intensified accumulation of dry mass of green stem with advancing cutting age. In agreement with Cutrim Junior (2006), the leaf/stem ratio is important because it reports the forage quality as well as the probability of apprehension of the most nutritional part of the plant (green leaves). Therefore, Pinto et al. (1994) advocated the value of 1.0 as the critical limit for the leaf/ stem ratio. In this study, it was verified that all the values of leaf/stem are below this threshold.

\section{Conclusions}

Echinochloa pyramidalis can be irrigated using water with electrical conductivity of up to $2.0 \mathrm{dS} \mathrm{m}^{-1}$, without affecting its biomass components. The cutting of Echinochloa pyramidalis should be done at 21 days, for presenting the best leaf/stem ratio.

\section{References}

ANNANDALE, J.G.; JOVANOVIC, N.Z.; BENADÉ, N. et al. Modelling the long-term effect of irrigation with gypsiferous water on soil and water resources. Agriculture, Ecosystem and Environment, v.76, p.109-119, 1999.

AQUINO, A.J.S.; LACERDA, C.F.; BEZERRA, M.A. et al. Crescimento, partição de matéria seca e retenção de $\mathrm{Na}^{+}, \mathrm{K}^{+} \mathrm{e}$ $\mathrm{Cl}^{-}$em dois genótipos de sorgo irrigados com águas salinas. Revista Brasileira de Ciências do Solo, v.31, p.961-971, 2007.

AYRES, R.S.; WESCOT, D.W. A qualidade da água na agricultura. Tradução de GHEYI, H.R.; MEDEIROS, J.F.; DAMASCENO, F.A.V. Campina Grande: UFPB, 1999. 153p.

BARBOSA, R.A. Características morfofisiológicas e acúmulo de forragem em capim-Tanzânia (Panicum maximum Jacq. cv. Tanzânia) submetido a freqüências e intensidades de pastejo. 2004. 119f. Tese (Doutorado em Zootecnia) Universidade Federal de Viçosa, Viçosa, MG.

BROUGHAM, R.W. Interception of light by the foliage of pure and mixed stands of pasture plants. Australian Journal of Agricultural Research, v.9, n.1, p.39-52, 1958.

BUENO, A.A.O. Características estruturais do dossel forrageiro, valor nutritivo e produção de forragem em pastos de capim Mombaça submetidos a regime de lotação intermitente. 2003. 124f. (Mestrado em Agronomia) - Escola Superior de Agricultura Luiz de Queiroz/USP, Piracicaba.

CÂNDIDO, M.J.D. Morfofisiologia e crescimento do dossel e desempenho animal, em Panicum maximum, cv. Mombaça sob lotação intermitente com três períodos de descanso. 2003. 134f. Tese (Doutorado em Zootecnia) - Universidade Federal de Viçosa, Viçosa, MG.

CUTRIM JUNIOR, J.A.A. Crescimento e morfofisiologia do dossel do capim Tanzânia com três freqüências de desfolhação e dois resíduos pós-pastejo. 2007. $106 f$. Dissertação (Mestrado em Zootecnia), Universidade Federal do Ceará, Fortaleza. 
EMPRESA BRASILEIRA DE PESQUISA AGROPECUÁRIA EMBRAPA. Manual de métodos de análises do solo. 2.ed. Versão atualizada. Rio de Janeiro: CNPS, 1997. 212p.

EPSTEIN, E. Nutrição mineral de plantas: princípios e perspectivas. São Paulo: EDUSP, 1975. 341p.

GHEYI, H.R. Problemas de salinidade na agricultura irrigada. In: OLIVEIRA, T.S.; ASSIS JUNIOR, R.N.; ROMERO, R.E. et al. (Eds). Agricultura, sustentabilidade e o semi-árido. Fortaleza: Sociedade Brasileira de Ciências do Solo, 2000. p.329-346.

GREENWAY, H.; MUNNS, R. Mechanisms of salt tolerance in non-halophytes. Plant Physiology, v.31, p.149-190, 1980.

HUNT, L.A. Some implications of death and decay in pasture production. Journal of the British Grassland Society, v.20, n.1, p.27-31, 1965.

KORTE, C.J.; WATKIN, B.R.; HARRIS, W. Use of residual leaf area index and light interception as criteria for spring-grazing management of ryegrass dominant pasture. New Zealand Journal of Agricultural Research, v.25, p.309-319, 1982.

LARCHER, W. Ecofisiologia vegetal. São Carlos: RiMa, 2000. 533p.

LOPES, R.S.; FONSECA, D.M.; OLIVEIRA, R.A.; et al. Efeito da irrigação e adubação na disponibilidade e composição bromatológica da massa seca de lâminas foliares de capimelefante. Revista Brasileira de Zootecnia, v.34, n.1, p.20-29, 2005.

LUTTS, S.; KINET, J.M.; BOUHARMONT, J. $\mathrm{NaCl}$ - induced senescence in leaves of rice (Oryza sativa L.) cultivars differing in salinity resistance. Annals of Botany, v.78, p.389-398, 1996.

MUNNS, R. Comparative physiology of salt and water stress. Plant and Cell Environment, v.25, p.239-250, 2002.
PINTO, J.C.; GOMIDE, J.A.; MAESTRI, M. Produção de matéria seca e relação folha caule de gramíneas forrageiras tropicais, cultivadas em vasos com duas doses de nitrogênio. Revista Brasileira de Zootecnia, v.23, p.313-326, 1994.

PRISCO, J.T.; O'LEARY, J.W. Enhancement of intact bean leaf senescence by $\mathrm{NaCl}$ salinity. Physiology Plant, v.27, p.95-100, 1972.

RHOADES, J.P.; KANDIAH, A.; MASHALI, A.M. The use saline waters for crop production. Roma: FAO, 1992. 133p. (Irrigation and Drainage Paper, 48).

SECKLER, D.; AMARASINGHE, U.; MOLDEM, D. et al. World water demand and supply, 1990 to 2025: Scenarios and Issues. Colombo: International Water Management Institute, 1998. 41p. (Research Report, 19).

SHARMA, D.P.E.; RAO, K.V.G.K. Strategy for long term use of saline drainage water for irrigation in semi-arid regions. Soil e Tillage Research, v.48, p.287-295, 1998.

SILVA, J.S.; LACERDA, C.F.; AZEVEDO NETO, A.D. et al. Crescimento e osmoregulação de dois genótipos de sorgo submetidos ao estresse salino. Ciência Agronômica, v.34, p.125-131, 2003.

SILVA, R.G. Morfofisiologia, valor nutritivo e produção animal em pasto de capim Tanzânia sob lotação rotativa por ovinos. 2004. 114f. Dissertação (Mestrado em Zootecnia) Universidade Federal do Ceará, Fortaleza.

SOUZA, E.M.; ISEPON, O.J.; ALVES, J.B. et al. Efeitos da irrigação e adubação nitrogenada sobre a massa de forragem de cultivares de Panicum maximum Jacq. Revista Brasileira de Zootecnia, v.34, n.4, p.1146-1155, 2005.

TAIZ, L.; ZEIGER, E. Fisiologia vegetal. Porto Alegre: Artmed, 2004. 719p. 